\title{
Impact of Intermetallic Precipitates on the Tribological and/or Corrosion Performance of Cast Aluminium Alloys: a Short Review
}

\author{
David Culliton \\ Technological University Dublin, david.culliton@tudublin.ie \\ Tony Betts \\ Technological University Dublin, anthony.betts@tudublin.ie \\ David Kennedy \\ Technological University Dublin, david.kennedy@tudublin.ie
}

Follow this and additional works at: https://arrow.tudublin.ie/engschmecart

Part of the Materials Science and Engineering Commons

\section{Recommended Citation}

Culliton, D., Betts, A. J. and Kennedy, D. (2013) Impact of Intermetallic Precipitates on the Tribological and/or Corrosion Performance of Cast Aluminium Alloys: a Short Review. International Journal of Cast Metals Research, 2013, VOL 26, NO 2, 65. doi:10.1179/1743133612Y.0000000038

This Article is brought to you for free and open access by the School of Mechanical and Design Engineering at ARROW@TU Dublin. It has been accepted for inclusion in Articles by an authorized administrator of ARROW@TU Dublin. For more information, please contact arrow.admin@tudublin.ie, aisling.coyne@tudublin.ie, gerard.connolly@tudublin.ie.

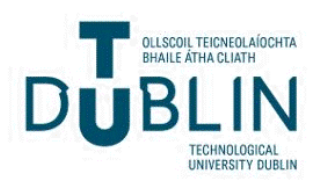




\title{
Impact of intermetallic precipitates on the tribological and/or corrosion performance of cast aluminium alloys: a short review
}

\author{
D. Culliton*1, A. J. Betts ${ }^{2}$ and D. Kennedy ${ }^{1}$
}

The role of various intermetallic precipitates (IMPs), or secondary phase particles, in governing the wear and corrosion performance characteristics of cast aluminium alloys is outlined in this brief review. Such alloys are especially important in transport applications where their low weight, low cost and recyclability make them very attractive. However, alloy wear and/or corrosion behaviour often limit their industrial application, and more work needs to be carried out to extend their use into other areas. Careful control of IMP nucleation and growth rates may be beneficial, especially in alloys exposed to corrosive environments. Silicon, copper and magnesium are all important elements for enhanced mechanical strength and tribological performance but often to the detriment of alloy corrosion resistance. Other elements such as iron may also play a significant role in deleterious IMP formation. Use of dispersoids based on novel (quasicrystals) seed alloys with similar lattice characteristics to the $\alpha$-Al matrix may result in further exploitation of these alloys.

Keywords: Cast aluminium alloys, Intermetallics, Dispersoids, Quasicrystals, Corrosion, Wear

\section{Introduction}

The automotive industry needs to produce cost efficient integral components of complex geometry, and casting is the most pragmatic solution. In addition, aluminium is the most abundant metal in the Earth's crust. ${ }^{1}$ As a result, since 2006, alloys of this metal have become the second most used materials in the automotive industry (Table 1), and global consumption of aluminium is predicted to double between 2006 and $2020 .^{2}$ This has made the automotive industry the largest market for aluminium alloys, more than half of which are cast $\mathrm{Al}$ alloys (Table 2). This transition has been primarily motivated by two global concerns:

(i) the depletion of world resources, necessitating the use of lighter, more abundant materials

(ii) international pressure by governments compelling industry to replace heavier metals with lighter, more efficient, recyclable materials. For instance, the EU End of Life Vehicles Directive (2000/53/ EC), published in 2000 , states that $85 \%$ of an end of life vehicle by weight will be recycled by the year 2006 , increasing to $95 \%$ by the year 2015 .

In conjunction with the economic implications of low cost casting techniques, greater product efficiencies can be achieved by incorporating light metal alloys. For

${ }^{1}$ Department of Mechanical Engineering, Dublin Institute of Technology, Bolton Street, Dublin 1, Ireland

${ }^{2}$ College of Sciences \& Health and 'Applied Electrochemistry Group, Focas Institute', Dublin Institute of Technology, Kevin Street, Dublin 8 , Ireland

*Corresponding author, email daveculliton@eircom.net instance, in vehicles, a weight reduction of $10 \%$ can increase fuel economy by $6-8 \%{ }^{3}$ Substituting Al alloys for steel and grey cast iron can achieve a weight reduction of up to $50 \%$ and allow savings of $\sim 3000 \mathrm{~L}$ of fuel and $7500 \mathrm{~kg}$ of $\mathrm{CO}_{2}$ over the lifetime of an average car. ${ }^{4}$ However, cast $\mathrm{Al}$ alloys are currently only used in either

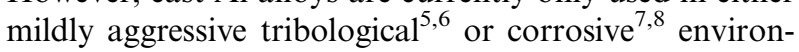
ments. This is related to the alloy microstructures and, more specifically, intermetallic precipitates (IMPs). Greater control of IMP growth in cast Al alloys could result in further exploitation of these alloys.

The tribological, mechanical and corrosion properties of cast Al alloys are defined by the solid solubilities of alloying elements and impurities present in the melt. The properties of the resultant IMP phases control both the mechanical and electrochemical properties of the alloy through their morphology, hardness, distribution and chemistry. Control of these precipitated phases is therefore key to improving and defining the properties of these alloys. Small, well distributed, spherical precipitates can be beneficial to both wear and mechanical properties and corrosion resistance. Inversely, large, acicular precipitates act as crack and corrosion initiators, thus diminishing the properties of the alloy. Heat treatments are used to redistribute and resize IMPs, but these treatments may lead to surface activation and a reduction in the corrosion resistance of the alloy. ${ }^{15,16}$

This short review identifies novel techniques for simultaneous improvement of both the mechanical properties and corrosion resistance of typical cast automotive $\mathrm{Al}$ alloys thereby expanding their industrial future beyond current applications. 
Table 1 Main alloying elements and typical intermetallic phases (IMP) of typical cast aluminium alloys used in automotive industry $(242 \cdot 0 / \mathrm{A242} \cdot 0$ also contain $1 \cdot 70-2 \cdot 30 \% \mathrm{Ni})$

\begin{tabular}{|c|c|c|c|c|c|c|c|}
\hline Alloy & $\mathrm{Si} / \%$ & $\mathrm{Cu} / \%$ & $\mathrm{Fe} / \%$ & $\mathrm{Mn} / \%$ & $\mathrm{Mg} / \%$ & $\mathrm{Zn} / \%$ & Typical IMPs \\
\hline $242 \cdot 0$ & 0.60 max. & $3 \cdot 70-4 \cdot 50$ & 0.1 max. & $0 \cdot 10$ max. & $1 \cdot 30-1 \cdot 70$ & $0 \cdot 10$ max. & $\beta-\mathrm{Al}_{5} \mathrm{FeSi}^{9}{ }^{9} \mathrm{Al}_{2} \mathrm{Cu}, \mathrm{Al}_{6} \mathrm{Cu}_{3} \mathrm{Ni}, \mathrm{Al}_{3} \mathrm{Ni}$ \\
\hline $\mathrm{A} 242 \cdot 0$ & 0.60 max. & $3 \cdot 70-4 \cdot 50$ & $0.8 \max$ & 0.10 max. & $1 \cdot 20-1 \cdot 70$ & 0.10 max. & $\mathrm{Al}(\mathrm{Ni}, \mathrm{Cu})_{2}, \mathrm{Al}_{7} \mathrm{Cu}_{2} \mathrm{Fe}, \mathrm{Al}_{20} \mathrm{Cu}_{3} \mathrm{Mn}_{2}$ \\
\hline $319 \cdot 0$ & $5 \cdot 50-6 \cdot 50$ & $3 \cdot 0-4 \cdot 0$ & 1.0 max. & 0.50 max. & $0 \cdot 10$ max. & 0.10 max. & $\beta-\mathrm{Al}_{5} \mathrm{FeSi}, \mathrm{Mg}_{2} \mathrm{Si}, \mathrm{Al}_{2} \mathrm{Cu},{ }^{10} \mathrm{Al}_{5} \mathrm{Mg}_{8} \mathrm{Si}_{6} \mathrm{Cu}_{2}$ \\
\hline A319.0 & $5 \cdot 50-6 \cdot 50$ & $3 \cdot 0-4 \cdot 0$ & 1.0 max. & 0.50 max. & $0 \cdot 10$ max. & 3.0 max. & \\
\hline B319.0 & $5 \cdot 50-6 \cdot 50$ & $3 \cdot 0-4 \cdot 0$ & $1 \cdot 2 \max$ & 0.50 max. & $0 \cdot 10-0.50$ & 1.0 max. & \\
\hline $356 \cdot 0$ & $6 \cdot 50-7 \cdot 50$ & 0.25 max. & 0.60 max. & 0.35 max. & $0 \cdot 20-0 \cdot 45$ & 0.35 max. & $\alpha-\mathrm{Al}_{8} \mathrm{Fe}_{2} \mathrm{Si}^{11,12} \mathrm{Mg}_{2} \mathrm{Si}, \beta-\mathrm{Al}_{5} \mathrm{FeSi}$ \\
\hline A356.0 & $6 \cdot 50-7 \cdot 50$ & 0.20 max. & $0 \cdot 20$ max. & 0.10 max. & $0 \cdot 25-0 \cdot 45$ & 0.10 max. & $\mathrm{Al}_{8} \mathrm{Mg}_{3} \mathrm{FeSi}_{6}$ \\
\hline A380.0 & $7 \cdot 50-9 \cdot 50$ & $3 \cdot 0-4 \cdot 0$ & $1 \cdot 30$ max. & 0.50 max. & 0.10 max. & 3.0 max. & $\beta-\mathrm{Al}_{5} \mathrm{FeSi}, \mathrm{Al}_{2} \mathrm{Cu}, \delta-\mathrm{Al}_{8} \mathrm{Mg}_{3} \mathrm{FeSi}_{6}$ \\
\hline B380.0 & $7 \cdot 50-9 \cdot 50$ & $3 \cdot 0-4 \cdot 0$ & $1 \cdot 30$ max. & 0.50 max. & 0.10 max. & $1 \cdot 0$ max. & $\mathrm{Al}_{5} \mathrm{Mg}_{8} \mathrm{Cu}_{2} \mathrm{Si}_{6}$ \\
\hline A390.0 & $16 \cdot 0-18 \cdot 0$ & $4 \cdot 0-5 \cdot 0$ & 0.50 max. & 0.10 max. & $0 \cdot 45-0.65$ & 0.10 max. & $\mathrm{Mg}_{2} \mathrm{Si}, \mathrm{Al}_{2} \mathrm{Cu}, \mathrm{Al}_{5} \mathrm{Cu}_{2} \mathrm{Mg}_{8} \mathrm{Si}_{6}$ \\
\hline B390.0 & $16 \cdot 0-18 \cdot 0$ & $4 \cdot 0-5 \cdot 0$ & $1 \cdot 30$ max. & 0.50 max. & $0 \cdot 45-0 \cdot 65$ & 1.50 max. & \\
\hline
\end{tabular}

\section{Discussion}

Typically, automotive components must have dynamic thermal and mechanical stability, good high temperature and fatigue strength, low thermal expansion and good wear resistance. ${ }^{17}$ In addition, resistance to localised corrosion degradation processes, such as pitting, galvanic and filiform corrosion, in the presence of hydroxides $\left(\mathrm{OH}^{-}\right)$, halides $\left(\mathrm{Cl}^{-}\right)$and sulphates $\left(\mathrm{SO}_{4}^{2-}\right)$ improves the life to failure of the components. These requirements are strongly related to the alloying elements used. In cast automotive $\mathrm{Al}$ alloys, primary alloying elements include $\mathrm{Si}, \mathrm{Cu}$ and $\mathrm{Mg}$. While silicon improves the castability of the alloys through improved fluidity and increased tendency to isothermal solidification, ${ }^{18}$ it also increases the wear resistance of the alloy. Mg improves the strength and hardness of the alloy through the precipitation of the $\mathrm{Mg}_{2} \mathrm{Si}$ IMP. In combination with copper, the strength and hardness of the resultant castings are further improved due to the precipitation of the $\mathrm{Al}_{2} \mathrm{Cu}$ or $\mathrm{Al}_{2} \mathrm{CuMg}$ IMPs. While Al-Cu (2xx.x) alloys tend to have higher yield and tensile strengths over a wider temperature range than $\mathrm{Al}-\mathrm{Si}-\mathrm{Mg}$ (3xx.x) alloys, the presence of $\mathrm{Cu}$ severely impacts their corrosion resistance. ${ }^{19}$

In cast $\mathrm{Al}$ alloy development, the key to success has been controlling and manipulating the size, morphology, distribution and composition of the IMPs. ${ }^{20}$ However, while modifiers, such as $\mathrm{Sr}^{21}$ and $\mathrm{Be}^{22}$ can be used to control grain growth, they will not affect the morphology and composition of the IMPs. Therefore, mechanical properties can be improved without affecting the corrosion resistance of the alloy, and, in the absence of a surface treatment, potential applications for Al alloys continue to be restricted.

\section{Intermetallics}

The precipitation and growth of the IMPs is dependent on the solid solubility of the respective alloying elements in the $\alpha$-Al matrix and in each other (Table 3 ). The resultant microstructural developments define the subsequent tribological and corrosion properties of the alloys. Typically, coarse particles with sizes larger than $1 \mu \mathrm{m}$ will deteriorate properties ${ }^{20}$ such as toughness and fatigue performance, and are detrimental to the corrosion resistance of the alloys. This is also dependent on the alloying elements present. For example, the $\alpha-\mathrm{Al}_{12}(\mathrm{Fe}, \mathrm{Mn}) \mathrm{Si}$ has significantly higher hardness (Table 4) than the $\mathrm{Al}_{6} \mathrm{Mn}$, $\mathrm{Al}_{6}(\mathrm{Fe}, \mathrm{Mn})$ and $\alpha-(\mathrm{AlMnSi})$ phases and is much more desirable for wear related tribological applications. ${ }^{23-25} \mathrm{In}$ addition, IMPs with structures such as Chinese Script are preferred to coarse, acicular structures due to reduced impact on the mechanical properties. ${ }^{26}$

In addition, alloying elements can also affect the development of other IMPs. For example, the presence of $\mathrm{Cu}$ leads to a change in the morphology of the eutectic Si particles from a coarse flake-like form to a fine fibrous one, ${ }^{27}$ with a resultant improvement in tribological performance. $\mathrm{Mg}$ can interfere with the precipitation of $\mathrm{Al}_{2} \mathrm{Cu}$ and, if present in relatively high amounts $(>0.05 \%)$, can promote the precipitation of $\mathrm{Al}_{2} \mathrm{MgCu}$ (S phase) and $\mathrm{Al}_{4} \mathrm{CuMg}_{5} \mathrm{Si}_{4}$. In the presence of $\mathrm{Cu}, \mathrm{Mn}$ precipitates out as a dispersoid ( $\mathrm{T}$ $\mathrm{Al}_{20} \mathrm{Cu}_{2} \mathrm{Mn}_{3}$ ), which has limited effect on mechanical properties but can aid grain size control. ${ }^{28}$ Since the $\alpha$-Al matrix can only contain $\mathrm{Si}, \mathrm{Cu}, \mathrm{Mg}$ and $\mathrm{Zn}$, the presence of other chemical elements, such as $\mathrm{Fe}, \mathrm{Mn}$ and $\mathrm{Ni}$, will only develop intermetallic phases. ${ }^{29}$ The size, morphology and chemistry of these IMPs strongly influence the

Table 2 Examples of automotive cast Al alloys, their typical uses and main failure modes: typically automotive corrosion occurs in form of pitting or galvanic corrosion caused by exposure to chloride $\left(\mathrm{Cl}^{-}\right)$or sulphate $\left(\mathrm{SO}_{4}^{2-}\right)$ environments

\begin{tabular}{|c|c|c|}
\hline Alloy & Typical components ${ }^{13}$ & Predominant degradation process(es) \\
\hline $242 \cdot 0$ & $\begin{array}{l}\text { Heavy duty pistons, aircraft generator housings, } \\
\text { air cooled cylinder heads }\end{array}$ & Wear (abrasive, adhesive) \\
\hline $319 \cdot 0$ & $\begin{array}{l}\text { Engine crankcases, petrol and oil tanks, oil pans, } \\
\text { water cooled cylinder heads, rear axle housings }\end{array}$ & Corrosion $^{14}$ \\
\hline $356 \cdot 0$ & $\begin{array}{l}\text { Flywheel housings, automotive transmission cases, } \\
\text { oil pans, rear axle housings, brackets, water cooled } \\
\text { cylinder blocks, various fittings and pump bodies }\end{array}$ & Corrosion \\
\hline A380.0 & Air brake castings, gear cases, air cooled cylinder heads & Tribological (friction) \\
\hline A390.0 & $\begin{array}{l}\text { Internal combustion engine pistons and blocks, cylinder } \\
\text { bodies for compressors, pumps and brakes }\end{array}$ & Wear (abrasive, adhesive) \\
\hline
\end{tabular}


Table 3 Possible intermetallic precipitates formed in typical automotive cast Al alloys

\begin{tabular}{|c|c|c|c|c|c|c|c|}
\hline \multicolumn{4}{|c|}{ Constituent phases in $2 x x . x$ alloys } & \multicolumn{4}{|c|}{ Constituent phases in $3 x x . x$ alloys } \\
\hline \multicolumn{2}{|l|}{$\begin{array}{l}\text { Intermetallic } \\
\text { phase }\end{array}$} & \multirow{2}{*}{$\begin{array}{l}\begin{array}{l}\text { Typical } \\
\text { size/ } / \mu \mathrm{m}\end{array} \\
5-12^{30}\end{array}$} & Morphology & \multicolumn{2}{|l|}{$\begin{array}{l}\text { Intermetallic } \\
\text { phase }\end{array}$} & Typical size/ $\mu \mathrm{m}$ & Morphology \\
\hline $\mathrm{Si}$ & & & Acicular & $\mathrm{Si}$ & & $5-12$ & Acicular \\
\hline $\mathrm{Al}_{2} \mathrm{Cu}$ & $\theta$ & $<50^{31}$ & Angular globule & $\mathrm{Al}_{2} \mathrm{Cu}$ & $\theta$ & $<50$ & Angular globule \\
\hline $\mathrm{Al}_{2} \mathrm{CuMg}$ & $S$ & $0 \cdot 5-10^{32}$ & $\begin{array}{l}\text { Irregular round } \\
\text { particles }\end{array}$ & $\mathrm{Al}_{2} \mathrm{CuMg}$ & S & $0 \cdot 5-10$ & Irregular round particles \\
\hline $\mathrm{Al}_{7} \mathrm{Cu}_{2} \mathrm{Fe}$ & $\omega$ & $0 \cdot 7-2 \cdot 7^{33}$ & Thin needles & $\mathrm{Al}_{7} \mathrm{Cu}_{2} \mathrm{Fe}$ & $\omega$ & $0 \cdot 7-2 \cdot 7$ & Thin needles \\
\hline $\mathrm{Al}_{5} \mathrm{Cu}_{2} \mathrm{Mg}_{8} \mathrm{Si}_{6}$ & Q & $<20^{34}$ & Honeycomb & $\mathrm{Al}_{5} \mathrm{Cu}_{2} \mathrm{Mg}_{8} \mathrm{Si}_{6}$ & Q & $<20$ & Honeycomb \\
\hline & & & & AlFeSi & $\beta$ & $50-150 \mu \mathrm{m}^{35}$ & Needles \\
\hline $\mathrm{Al}_{12}(\mathrm{FeMn})_{3} \mathrm{Si}$ & $\alpha$ & $<0 \cdot 5^{36}$ & $\begin{array}{l}\text { Polyhedra, Chinese } \\
\text { Script }\end{array}$ & $\mathrm{Al}_{12}(\mathrm{FeMn})_{3} \mathrm{Si}$ & $\alpha$ & $<0.5$ & Polyhedra, Chinese Script \\
\hline $\mathrm{Al}_{20} \mathrm{Cu}_{2} \mathrm{Mn}_{3}$ & $\mathrm{~T}$ & $<0 \cdot 1^{37}$ & Dispersoid & $\mathrm{Al}_{20} \mathrm{Cu}_{2} \mathrm{Mn}_{3}$ & $\mathrm{~T}$ & $<0 \cdot 1$ & Dispersoid \\
\hline & & & & $\mathrm{Mg}_{2} \mathrm{Si}$ & $\beta$ & $\sim 10^{38}$ & Lamellar, rod-like 39 \\
\hline & & & & $\mathrm{Al}_{8} \mathrm{Mg}_{3} \mathrm{FeSi}_{2}{ }^{40}$ & $\pi$ & $<0.5$ & Chinese script \\
\hline
\end{tabular}

mechanical properties and corrosion resistance of the resultant alloys (Table 4).

Generally speaking, the larger the IMP, the more detrimental it is likely to be to both the mechanical/ tribological performance of the alloy and its corrosion resistance. For example, above a critical IMP size $(1 \mu \mathrm{m})$, a direct relationship between corrosion rate and IMP size has been reported by Colley et al. ${ }^{41}$ who found a decrease in the corrosion rate with decreasing IMP size. IMPs that grow freely within the solidifying liquid tend to grow much larger than those that form during or after the period of Al-Si eutectic solidification. By increasing the cooling rate, pooling of the alloying elements between the dendrite arms may be controlled and IMP growth can be restricted. This may lead to a more homogeneous microstructure with smaller, morphologically benign, more dispersed IMPs. It has been shown that, as the cooling rate decreases, the average IMP size increases and the strength of the casting decreases. ${ }^{42}$ Therefore, the key to simultaneous improvement of both the mechanical properties and the corrosion resistance of $\mathrm{Al}$ alloys is through controlled precipitation of the IMP phases by expediting $\alpha$-Al grain nucleation, reducing the secondary dendrite arm spacing (SDAS) and homogenising solidification rates throughout the casting.

\section{Tribology, corrosion and environments}

Wear resistant cast Al Alloys are based on the Al-Si alloy range, due to their relatively high density $\left(2.6 \mathrm{~g} \mathrm{~cm}^{-3}\right)$ and the excellent hardness of the diamond cubic shaped silicon phase (Table 4 ). In addition, they possess low thermal expansion coefficients, relatively good corrosion resistance and favourable mechanical properties. ${ }^{43}$ Higher silicon content improves fluidity, feeding characteristics and hot cracking resistance ${ }^{44}$ but may also lead to reduced density of the casting, ${ }^{45}$ increase in porosity and surface roughness ${ }^{46}$ and, above $11 \%$, can reduce the wear resistance of the alloy. ${ }^{47} \mathrm{Si}$ particle morphology and density can be altered through the addition of $\mathrm{Sr}^{30}$

Bai and Biswas ${ }^{48}$ and Sarkar and Clarke ${ }^{49}$ have stated that the silicon content has no influence on the friction coefficient of Al-Si alloys. In contrast, Mahato et al. ${ }^{50}$ has suggested that the proliferation and morphology of protruding silicon particles could lead to an increase in wear resistance. However, this is only possible if the working pressure of the sliding system is less than that of the yield strength of the aluminium matrix $(\sim 80 \mathrm{MPa})$, as at higher loads the particles disintegrate and become dispersed in the deformed layer. ${ }^{51}$ Subramanain $^{47}$ reported that, in wear applications, additions of up to

Table 4 Typical phases found in 2xx.x and 3xx.x cast aluminium alloys and their reported hardness and corrosion potentials in various $\mathrm{NaCl}$ molar solutions

\begin{tabular}{|c|c|c|c|c|}
\hline \multirow[b]{2}{*}{ Main alloying elements and intermetallic phases } & \multirow[b]{2}{*}{ Hardness/GPa } & \\
\hline & & $0.01 \mathrm{M}$ & $0 \cdot 1 \mathrm{M}$ & $0.6 \mathrm{M}$ \\
\hline$\alpha-\mathrm{Al}$ & $0 \cdot 167$ & -679 & -823 & -849 \\
\hline $\mathrm{Si}$ & $10 \cdot 0^{55}-3 \cdot 3^{56}$ & -450 & -441 & -452 \\
\hline $\mathrm{Cu}$ & 0.369 & -177 & -232 & -220 \\
\hline $\mathrm{Mg}$ & 0.462 & -1601 & -1586 & -1688 \\
\hline $\mathrm{Al}_{3} \mathrm{Fe}$ & $7 \cdot 36^{57}$ & -493 & -539 & -566 \\
\hline$\alpha$-AlFeSi $\left(\mathrm{Al}_{8} \mathrm{Fe}_{2} \mathrm{Si}, \mathrm{Al}_{12} \mathrm{Fe}_{3} \mathrm{Si}_{2}\right)^{58}$ & $12 \cdot 3-14 \cdot 9^{59}$ & & & \\
\hline$\beta$-AlFeSi $\left(\mathrm{Al}_{5} \mathrm{FeSi}\right)$ & $5 \cdot 8^{60}$ & & & \\
\hline$\gamma$-AlFeSi $\left(\mathrm{Al}_{3} \mathrm{FeSi}\right)$ & $15 \cdot 6-17 \cdot 4^{59}$ & & & \\
\hline$\alpha-\mathrm{Al}_{12}(\mathrm{Fe}, \mathrm{Mn})_{3} \mathrm{Si} / \mathrm{Al}_{15}(\mathrm{Fe}, \mathrm{Mn})_{3} \mathrm{Si}$ & $4 \cdot 74^{61}$ & & & \\
\hline$\pi-\mathrm{Al}_{8} \mathrm{FeMg}_{3} \mathrm{Si}_{6}$ & $5 \cdot 85^{9}$ & & & \\
\hline$\beta-\mathrm{Mg}_{2} \mathrm{Si}$ & $4 \cdot 5^{55}$ & -1355 & -1538 & -1536 \\
\hline$\theta-\mathrm{Al}_{2} \mathrm{Cu}$ & $7 \cdot 6-8^{55}$ & -592 & -665 & -695 \\
\hline $\mathrm{S}-\mathrm{Al}_{2} \mathrm{CuMg}$ & $3 \cdot 7-3 \cdot 9^{55}$ & -956 & -883 & -1061 \\
\hline$\beta-\mathrm{Mg}_{2} \mathrm{Si}$ & $4 \cdot 5^{55}$ & -1355 & -1538 & -1536 \\
\hline$\omega-\mathrm{Al}_{7} \mathrm{Cu}_{2} \mathrm{Fe}$ & $9 \cdot 39^{62}$ & -549 & -551 & -654 \\
\hline $\mathrm{Q}-\mathrm{Al}_{5} \mathrm{Cu}_{2} \mathrm{Mg}_{8} \mathrm{Si}_{6}$ & $6 \cdot 51^{63}$ & & & \\
\hline
\end{tabular}


$11 \% \mathrm{Si}$ improved the wear resistance, while above $11 \%$, the wear rate increased again. As Si content increases, Si particle size increases, sometimes up to $2-3 \mu \mathrm{m},{ }^{52}$ which can be detrimental to strength, ductility and fracture toughness. $^{53}$

Prasad et al. ${ }^{64}$ reported on the improvement in wear properties for refined $\mathrm{Al}-\mathrm{Si}$ microstructures. In their study of the effect of silicon content on the wear resistance of Al-Si alloys (LM13 [Al-Si12CuFe] and LM29 [Al-Si23CuMgNi]), they showed that the mechanical and wear properties of the castings were a function of the size and amount of primary silicon present. Refining the primary silicon particles and, as a consequence, the SDAS, through choice of casting process, produced castings with superior wear properties. The importance of $\mathrm{Si}$ phase refinement was also stressed by Yust ${ }^{65}$ who reported that, while small evenly dispersed particles improved ductility without reducing strength, coarse acicular particles reduced ductility because they acted as crack initiators. Post-treatments have been shown to alter the shape of the as cast silicon phase. ${ }^{66}$ It is suggested that this improvement comes from a refinement of the microstructure ${ }^{67}$ and alteration of the morphology of the silicon precipitates.

The wear properties of Al-Si alloys can be improved by the addition of some alloying elements, such as $\mathrm{Cu}$ and $\mathrm{Ni}$, which produce hard intermetallic phases. ${ }^{68}$ Beneficial effects are dependent on the size, distribution and morphology of these particles with smaller, well distributed, spherical particles considered to be more beneficial. For instance, in copper containing Al alloys, increased wear resistance has been associated with precipitation of the small, brittle $\theta-\mathrm{Al}_{2} \mathrm{Cu}$ phase at the surface. ${ }^{69}$ The addition of $1 \% \mathrm{Cu}$ to $\mathrm{Al}-\mathrm{Si}$ alloys increased the transition load for mild to severe wear by three to four times that of the original alloys by increasing the stability and strength of the surface layer. ${ }^{70}$ Hanafee $^{71}$ reported on the positive effect of magnesium, which precipitates out as a finely dispersed $\beta$ - $\mathrm{Mg}_{2} \mathrm{Si}$ under controlled precipitation, ${ }^{72}$ to the surface hardness of heat treated Al Alloys. However, these IMPs also impact the corrosion resistance of the alloys through the creation of galvanic cells with the surrounding $\alpha$-Al matrix in the presence of an aqueous solution.

The corrosion resistance of $\mathrm{Al}$ alloys is controlled by the composition and microstructure ${ }^{73}$ and is primarily affected by the $\alpha$-Al matrix phase. In the presence of aggressive ions $\left(\mathrm{Cl}^{-}, \mathrm{SO}_{4}^{2-}\right.$ and $\left.\mathrm{OH}^{-}\right)$, aluminium can be selectively dissolved, depending on the alloying elements present. The corrosion resistance of the $\alpha$-Al matrix phase is ennobled (made less negative relative to pure aluminium, Table 4) when $\mathrm{Fe}, \mathrm{Cu}, \mathrm{Mn}$ and $\mathrm{Si}$ are added, while $\mathrm{Mg}$ and $\mathrm{Zn}$ shift the potential to a less noble state $^{74}$ (made more negative relative to pure aluminium, Table 4). For each element, the significant changes in the corrosion resistance occur within the range in which the element is completely in solid solution. Further additions of the same element form microscopic second phase particles (shell particles) or IMPs. These IMPs, ${ }^{75}$ such as $\mathrm{Al}_{2} \mathrm{Cu}, \alpha$-AlFeSi, $\beta$ $\mathrm{Al}_{5} \mathrm{FeSi}, \mathrm{Al}_{3} \mathrm{Mg}_{2}$ or $\mathrm{Al}_{2} \mathrm{CuMg}$, prevent the homogeneous formation of a protective oxide layer ${ }^{76}$ and generally act as "active sites ${ }^{, 77}$ for corrosion initiation. ${ }^{78}$ This results in the localised dissolution of the $\alpha$-Al matrix, ${ }^{79-83}$ dealloying of the $\mathrm{Mg}$ based IMPs ${ }^{32,84}$ and the formation of corrosion pits. $^{85}$ Therefore, the corrosion resistance of an $\mathrm{Al}$ alloy is dependent on the size, composition and distribution of the IMPs and their relative nobility to the surrounding $\alpha$-Al matrix.

Corrosion resistance can be defined by the Open Circuit Potential or corrosion potential, $E_{\text {corr }}$, of the alloy in aqueous solutions and is related to the cathodically driven oxygen reduction reaction at and around the IMPs. Both $\mathrm{Cu}$ and Fe rich IMPs (more noble than the $\alpha$-Al matrix, Table 4) can serve as cathodes for this reaction with similar efficiency, ${ }^{86}$ thus driving the corrosion of the surrounding aluminium. Increasing the amount of $\mathrm{Cu}$ or $\mathrm{Fe}$ in an alloy increases the corrosion rate. ${ }^{87}$ However, IMPs capable of sustaining the largest cathodic current densities are not necessarily those with the noblest $E_{\text {corr }}$ (Table 4). Similarly, those with the least noble $E_{\text {corr }}$ will not necessarily sustain the largest anodic currents. ${ }^{54,88}$ Hence, not only thermodynamic but also kinetic aspects are important to consider when exploring the role of IMPs in corrosion degradation. However, a detailed discussion of these corrosion phenomena is outside the scope of this short review and can be found elsewhere. ${ }^{89}$

Birbilis and Buchheit ${ }^{54}$ reviewed the effect of IMP composition on the corrosion of a typical Al-Cu alloy. They found that, although the Fe IMPs were quantified as being more noble than the surrounding matrix, the $\mathrm{Cu}$ IMPs were far more deleterious. They attributed this to the ability of the IMPs to support extended cathodic reactions (oxygen reduction), which resulted in corrosion rates an order of magnitude higher than those of the $\mathrm{Fe}$ based IMPs. These $\mathrm{Cu}$ based IMPs are generally of the form $\mathrm{Al}_{2} \mathrm{Cu}$ or $\mathrm{Al}_{2} \mathrm{CuMg}$, and the higher corrosion rates may be related to the plating out of $\mathrm{Cu} .{ }^{90}$ As noted in Table 3, these IMPs are larger than the critical size of $1 \mu \mathrm{m}$. Since this behaviour is strongly linked with the size of the IMPs, as well as the composition, control of IMP precipitation and growth is critical to improving alloy properties especially in corrosive fluids.

\section{Intermetallic precipitation and solidification}

$\mathrm{Al}$ alloy solidification is a highly complex process. In general, however, three main solidification reactions are exhibited during the solidification process. ${ }^{91,92}$ Initially, aluminium dendrites (liquidus) are formed, followed by the development of two main eutectic phases. The presence of alloying and impurity elements, such as $\mathrm{Cu}$, $\mathrm{Mg}, \mathrm{Mn}$ and $\mathrm{Fe}$, leads to more complex constituents. Preliminary models of microstructural development, such as the isothermal melt model, ${ }^{93}$ were based on the free growth criterion, which assumed that the rate determining step to the formation of a grain is not nucleation, but rather overcoming the energy barrier relating to the curvature of the solid/liquid interface (the Gibbs-Thomson effect). These models are very simplistic and are only suitable for predicting grain size for a range of solute levels (inoculant particle populations) in small, slowly cooled castings.

Recent studies ${ }^{94,95}$ have shown that the solute elements in the liquid ahead of the growing crystals reduce the growth rate velocity of the nucleated crystals and increase the maximum undercooling achievable before recalescence. This allows more particles to be active in nucleation and, consequently, increases the number density of active particles, giving rise to a finer grain size. As a result, increasing the cooling rate can 
restrict the size, composition and morphology of the resultant IMPs.

Attempts to model the effect of alloy composition and cooling rate on the mechanical properties of these alloys have shown that smaller, more spherical intermetallics, combined with lower SDAS, produce the highest strength in the Al alloy. ${ }^{96,97}$ The SDAS depends on the chemical composition of the alloy, the solidification rate and the temperature gradient on the crystallisation front. In addition, the SDAS can control the precipitation and growth of IMPs. Therefore, the priority for property improvement must be to reduce the SDAS by increasing the cooling rate and in larger castings; this can only be achieved by introducing dispersoids into the melt.

\section{Dispersoids and intermetallics}

Dispersoids have been used successfully in many forms of aluminium alloy casting, and the ideal atomic structures of the dispersoid should be close to the face centred cubic (fcc) structure of the $\alpha$-Al matrix. As stated previously, one of the key properties of a successful dispersoid is its ability to be wetted by the alloy matrix. Traditionally, grain refiners were based on the Al-Ti-B ${ }^{98,99}$ or the Al$\mathrm{Ti}-\mathrm{C}^{100}$ systems. While these may have been reasonably successful, the resultant alloys were still limited by their properties. This may have been related to the structure of the dispersoids, which were hexagonal (Al-Ti-B) and octahedral (Al-Ti-C). It may also have been related to the low efficiency of the process, which can be $<1 \%{ }^{101}$ More importantly, these inoculants do not directly impact the formation and growth of IMPs.

In $\mathrm{Al}$ alloys, magnesium is the most widely used wetted element, ${ }^{18,42,102-104}$ most likely due to its fcc structure. However, while $\mathrm{MgO}$ has been used as a reinforcement in aluminium metal matrix composites, ${ }^{102}$ its use as a grain refining dispersoid has only been reported for cast magnesium alloys. ${ }^{105,112}$ Other oxides, such as aluminium $\left(\mathrm{Al}_{2} \mathrm{O}_{3}\right)$, have also been used in aluminium metal matrix composites, ${ }^{106}$ but due to their dissimilar molecular structure (hexagonal close packed), ${ }^{107}$ it is unlikely that they would be useful as nucleating dispersoids. Since the ideal dispersoid is one that has high temperature stability and produces distortion of the lattice structure but remains coherent with this structure, oxide based dispersoids may not be the solution. In addition, due to the large density differences between aluminium and the alloying elements, ${ }^{108}$ it is necessary to promote elevated solidification rates from the melt to prevent extensive pooling of the alloying elements. Therefore, novel nucleating dispersoids are required.

For most cast $\mathrm{Al}$ alloys, the maximum operating temperature is restricted to 150 to $175^{\circ} \mathrm{C} .{ }^{109}$ This has been attributed to the thermal instability and excessive growth of the strength providing IMPs, resulting in undesirable levels of lattice incoherencies, ${ }^{110}$ such as grain/ phase boundaries. These lattice incoherencies provide sites for void coalescence, resulting in crack formation and growth under mechanical loading. However, in 2002, engineers at National Aeronautics and Space Administration developed a range of cast Al alloys, which had superior mechanical properties at elevated temperatures (230$\left.400^{\circ} \mathrm{C}\right) .{ }^{111}$ This advancement was attributed to the stabilising effect of strengthening precipitates with an $\mathrm{L}_{2}$ crystal structure. The $\mathrm{L}_{2}$ crystal structure is a derivative of the fcc structure and is therefore highly coherent with the $\alpha$-Al matrix. These IMPs were based on an $\mathrm{Al}_{3} \mathrm{X}$ structure $(\mathrm{X}=\mathrm{Ti}, \mathrm{V}, \mathrm{Zr}){ }^{112}$ The high temperature stability of these precipitates, combined with the high level of coherence between the $\mathrm{L}_{2}$ structure and the fcc $\alpha$-Al matrix, provided the improved performances. The stability of these IMPs may be further enhanced using a $\mathrm{Ti}_{4} \mathrm{Al}_{14} \mathrm{X}(\mathrm{X}=\mathrm{Fe}, \mathrm{Ni}$ or $\mathrm{Cu})$ structured dispersoid, ${ }^{113}$ the stability of which increases with increasing atomic number $(\mathrm{Fe}<\mathrm{Ni}<\mathrm{Cu})$. This is similar, in concept, to aluminium metal matrix composites, and based on this concept, it may be possible to not only improve the tribological performance of the alloy but also to improve the corrosion resistance of the same alloys. As a result, it is strongly suggested that by augmenting current alloy production methods with novel alloying techniques, superior properties can be achieved with a wide range of cast Al alloys. A range of dispersoids, which, as yet, have not been considered for cast $\mathrm{Al}$ alloys but have been successfully incorporated into steel alloys with dramatic effect, ${ }^{114}$ are quasicrystals (QCs). ${ }^{115}$

\section{Novel dispersoids}

Quasicrystals, or quasi-periodic crystals, have a face centred icosahedral structure ${ }^{116}$ that is ordered but not periodic. ${ }^{117}$ Typical QC alloys include Al-Mn, Al-Mn-Si, ${ }^{18} \mathrm{Al}-\mathrm{Cu}-$ $\mathrm{Mn}^{119}$ or $\mathrm{Al}-\mathrm{Mg}-\mathrm{Cu}{ }^{120}$ Currently used as protective coatings $^{121}$ and in advanced steel alloys for medical applications, these materials have high hardness (low friction), excellent mechanical properties and high temperature stability. ${ }^{122}$ Similar to the $\mathrm{L1}_{2}$ additives used in the National Aeronautics and Space Administration alloys, these structures have the potential of promoting the development of a refined microstructure, with improved mechanical/tribological properties ${ }^{123}$ and corrosion resistance. This should not be confused with dispersion strengthening, where strength enhancing dispersoids are added directly to the melt. ${ }^{124}$ These QC alloys have high lattice coherency and high temperature stability, though minimal deformation has been noted in some QC alloys at temperatures in excess of $750^{\circ} \mathrm{C} .^{125}$ By selecting quasicrystalline submicrometre particles (minimum particle size can be quantified from a number of different models ${ }^{126,127}$ ) based on suitable seed alloys, which have similar lattice parameters to the base alloy (high lattice coherency), wetting of the dispersoid can be maximised. As a result, these quasicrystalline dispersoids should act as optimum nucleation primers, producing homogeneous microstructures with smaller, well dispersed IMPs, leading to concomitant improvement of mechanical properties and corrosion resistance. In addition, the proliferation of these nucleation primers, particularly in larger castings, would increase the tendency to isothermal solidification. This would lead to increased cooling rates and reduced recalescence temperatures, resulting in smaller grain size and influencing the morphology, composition and distribution of the developed IMPs. Since the mechanical properties of the alloy are related to the dispersoid concentration, ${ }^{128}$ greater dispersoid distribution would increase the strength of the resultant alloys. Based on the five requirements suggested by Wang et al., ${ }^{103}$ QCs could be the basis of an optimised solution for microstructural control in cast $\mathrm{Al}$ alloys and need to be investigated further.

\section{Conclusions}

Current casting techniques do not produce aluminium alloys with sufficient wear and/or corrosion resistance for use in any but the most benign service environments. 
Research aimed at improving their tribological and/or corrosion performance characteristics could potentially produce superior alloys, enabling their adoption in a more widespread industrial context and providing an opportunity to extend their use into new fields. These include applications in industries such as those in the burgeoning energy and marine sector, thus extending their somewhat limited use beyond the present transport sector (largely automotive and aerospace).

The tribological, mechanical and corrosion behaviour of cast Al alloys are largely defined by the solid solubilities of various alloying elements such as silicon, magnesium, copper and melt impurities. The resultant intermetallic phases can control alloy service performance through their morphology, hardness, distribution and chemical characteristics. Careful control of these precipitated phases is therefore essential. In general, small (i.e. submicrometre), evenly distributed, spherical precipitates can be beneficial to both wear and mechanical properties. In contrast large, acicular, precipitates may act as crack initiators, leading to reduced ductility. Although heat treatments are commonly used to redistribute and resize IMPs, these treatments may lead to surface activation with a concomitant reduction in the alloy's corrosion resistance.

Dispersoids can be added to the melt to increase grain nucleation rates and reduce solidification times. However, these do not sufficiently impact the resultant properties of the alloys due to their incompatible crystal structures. One possible novel approach may be to utilise dispersoids based on fcc compatible QCs, which may also provide enhanced mechanical and corrosion behaviour. These novel materials generally possess high temperature stability and some have shown improved corrosion resistance in corrosive fluids. However, these structures have not, heretofore, been considered as dispersoids in $\mathrm{Al}$ alloy casting melts.

It is suggested that these novel structures could act as potential dispersoids, particularly in casting technologies where no mechanical processing of the melt occurs, such as gravity and sand casting. In addition, the thermal stability of these dispersoids implies that the developed submicrometre IMP should remain stable during any subsequent heat treatment. Although it may not be possible to entirely eliminate precipitation of deleterious IMPs, by increasing the nucleation sites and the cooling rate, strict controls can possibly be placed on the size of these IMPs, which may be achieved by incorporating such QCs into the melt.

This brief review highlights the important role of IMPs in governing the behaviour of cast $\mathrm{Al}$ alloys and identifies possible ways to overcome some of their present limitations.

\section{References}

1. http://www.rsc.org/periodic-table/element/13/Aluminium (accessed May 2012)

2. Anon.: 'The global aluminum industry: review and forecast', $J O M, 2006, \mathbf{5 8}, 10-11$.

3. http://www.csiro.au/science/ps1jb.html (accessed May 2012).

4. R. Bähr, H. Mäsiar and J. Kasala: 'Innovations and perspectives in foundry science - castings in virtual reality', Proc. World Tech. Forum, Brno, Czech Republic, May-June 2009, Czech Foundry Society, Paper 5.

5. S. C. Tung and M. L. McMillan: Tribol. Int., 2004, 37, 517-536.

6. 'European technology platform for advanced engineering materials and technologies', EuMat Roadmap, V.27, 22, EuMat, Brussels, Belgium, 2006.
7. G. H. Koch, M. P. H. Brongers, N. G. Thompson, Y. P. Virmani and J. H. Payer: 'Corrosion costs and preventive strategies in the United States U.S. Federal Highway Administration Report', FHWA-RD-01-156, March 2002.

8. G. H. Koch, M. P. H. Brongers, N. G. Thompson, Y. P. Virmani and J. H. Payer: 'Cost of corrosion in the United States', in 'Handbook of environmental degradation of materials', (ed. M. Kutz), 8, 2005, Norwich, NY, William Andrew Publishing.

9. N. A. Belov, D. G. Eskin and A. A. Aksenov: 'Multicomponent phase diagrams: applications for commercial aluminum alloys', 159-192; 2005, Amsterdam, Elsevier Inc.

10. F. H. Samuel: J. Mater. Sci., 1998, 33, 2283-2297.

11. M. Merlin and G. L. Garagnani: Metall. Sci. Technol., 2009, 27, 21-30.

12. K. Y. Wen, W. Hu and G. Gottstein: Mater. Sci. Technol., 2003, 19, 762-768.

13. J. R. Davis: 'Aluminum and aluminum alloys', 95; 1993, Materials Park, OH, ASM International.

14. A. U. C. Maduako, G. C. Ofunner and C. M. Ojinnaka: Tribol. Int., 1996, 29, 153-160.

15. B. Graver, A. van Helvoort, J. C. Walmsley and K. Nisancioglu: Mater. Sci. Forum, 2006, 519-521, 673-678.

16. J. T. B. Gundersen, A. Aytaç, J. H. Nordlien and K. Nişancıoğlu: Corros. Sci., 2004, 46, 697-714.

17. Md. Al Mehedi: Int. Aluminium J., 2011, 87, 55-57.

18. D. Apelian: 'Aluminum cast alloys: enabling tools for improved performance'; 2009, Wheeling, IL, NADCA.

19. N. A. Belov, D. G. Eskin and A. A. Aksenov: 'Multicomponent phase diagrams: applications for commercial aluminum alloys', 146; 2007, Amsterdam, Elsevier.

20. G. Ran, J. Zhou and Q. G. Wang: J. Alloys Compd, 2006, 421, 80-86.

21. S. Z. Lu and A. Hellawell: J. Cryst. Growth, 1985, 73, 316-328.

22. Z. Chen, H. Zhang and R. Zhang: China Foundry, 2010, 7, 275-277.

23. D. L. Sun, S. B. Kang and H. S. Koo: Mater. Chem. Phys., 2000, 63, 37-43.

24. R. G. Kamat and S. Saimoto: Mater. Sci. Technol., 1994, 10, 215-221.

25. T. Sheppard: 'Extrusion of aluminium alloys', 108; 1999, Dordrecht, Kluwer Academic Publishers.

26. E. Tillová, M. Chalupová, L. Hurtalová, M. Bonek and L. A. Dobrzański: J. Achiev. Mater. Manuf. Eng., 2011, 47, 19-25.

27. L. A. Dobrzański, R. Maniara, M. Krupiński and J. H. Sokolowski: J. Achiev. Mater. Manuf. Eng., 2007, 24, 51-54.

28. L. del Castillo and E. J. Lavernia: Metall. Mater. Trans. A, 2000, 31A, 2287-2298.

29. V. S. Zolotorevskí, N. A. Belov and M. V. Glazoff: 'Casting aluminum alloys'; 2007, Amsterdam, Elsevier.

30. A. M. A. Mohamed, A. M. Samuel, F. H. Samuel and H. W. Doty: Mater. Des., 2009, 30, 3943-3957.

31. A. C. Vieira, A. M. Pinto, L. A. Rocha and S. Mischler: Electrochim. Acta, 2011, 56, 3821-3828.

32. Y. Yoon and R. G. Bucheit: J. Electrochem. Soc., 2006, 153, B151-B155.

33. N. Birbilis, M. K. Cavanaugh and R. G. Buchheit: Corros. Sci., 2006, 48, 4202-4215.

34. D. J. Chakrabarti and D. E. Laughlin: Prog. Mater. Sci., 2004, 49, 389-410.

35. J. Espinoza-Cuadra, P. Gallegos-Acevedo, H. Mancha-Molinar and A. Picado: Mater. Des., 2010, 31, 343-356.

36. J. A. Taylor: Proc. 35th Australian Foundry Institute National Conf., Adelaide, SA, Australia, October-November 2004, Australian Foundry Institute, 148-157

37. E. Saraloĝlu: 'Effect of ecap and subsequent heat treatments on microstructure and mechanical properties of 2024 aluminium alloy', MSc thesis, Middle East Technical University, Ankara, Turkey, 2008.

38. M. Usta, M. E. Glicksman and R. N. Wright: Metall. Mater. Trans. A, 2004, 35A, 435-438.

39. S. Li, S. Zhao, M. Pan, D. Zhao, X. Chen, O. M. Barabash and R. I. Barabash: Mater. Trans. JIM, 1997, 38, 553-559.

40. J. R. Davis: 'Aluminum and aluminum alloys', 31-46; 1993, Materials Park, OH, ASM International.

41. A. L. Colley, J. V. Macpherson and P. R. Unwin: Electrochem. Commun., 2008, 10, 1334-1336.

42. Y. M. Li and R. D. Li: Sci. Technol. Adv. Mater., 2001, 2, 277-280.

43. J. U. Ejiofor and R. G. Reddy: JOM, 1997, 49, 31-37.

44. J. R. Davies: 'Aluminium and aluminium alloys', 88-120; 1993, Materials Park, OH, ASM International.

45. S. P. Nikanorov, M. P. Volkov, V. N. Gurin, Yu. A. Burenkov, L. I. Derkachenko, B. K. Kardashev, L. L. Regel and W. R. Wilcox: Mater. Sci. Eng. A, 2005, A390, 63-69. 
46. D. Landolt, S. Mischler and M. Stemp: Electrochim. Acta, 2001, 46, 3913-3929.

47. C. Subramanain: Wear, 1991, 151, 97-110.

48. P. Bai and S. K. Biswas: Wear, 1987, 120, 61-74.

49. A. D. Sarkar and J. Clarke: Wear, 1980, 61, 157-167.

50. A. Mahato, S. Xia, T. Perry, A. K. Sachdev and S. K. Biswas: Tribol. Int., 2010, 43, 381-387.

51. N. Saka, A. M. Eleiche and N. P. Sub: Wear, 1977, 44, 109-125.

52. A. A. Benzerga, S. S. Hong, K. S. Kim, A. Needleman and E. van der Giessen: Acta Mater., 2001, 49, 3071-3083.

53. K. Lee, Y. N. Kwon and S. Lee: Eng. Fract. Mech., 2008, 75, 4200-4216.

54. N. Birbilis and R. G. Buchheit: J. Electrochem. Soc., 2005, 152, B140-B151.

55. M. Zamin: Corrosion, 1981, 37, 627-632.

56. S. Seifeddine and I. L. Svensson: Metall. Sci. Technol., 2010, 27, 11-20.

57. L. Dubourg, F. Hlawka and A. Cornet: Surf. Coat. Technol., 2002, 151-152, 329-332.

58. J. Namahoot: 'Effect of deformation on corrosion of Al-Mn alloys', $\mathrm{PhD}$ thesis, University of Birmingham, Birmingham, UK, 2004.

59. S. Murali, T. Sritharan and P. Hing: Intermetallics, 2003, 11, 279281

60. N. A. Belov and T. A. Kurdyumova: Izv. AN SSSR, Metally, 1989, 2, 210-215.

61. E. Tillová, M. Chalupová and L. Hurtalová: in 'Scanning electron microscopy', (ed. V. Kazmiruk), 411-438; 2012, Rijeka, InTech.

62. J. Le Donne: 'Mechanical behavior of aluminum intermetallics by nanoindentation', General Poster Session, Proc. Materials Science \& Technology 2009 Conf., Pittsburgh, PA, USA, October 2009, ASM International, Paper 129.

63. C.-L. Chen, A. Richter and R. C. Thomson: Intermetallics, 2010, 18, 499-508.

64. B. K. Prasad, K. Venkateswarlu, O. P. Modi, A. K. Jha, S. Das and R. Dasgupta: Metall. Mater. Trans. A, 1997, 29A, 2747-2752.

65. C. S. Yust: Tribol. Wear Int. Met. Rev., 1985, 30, 141-154.

66. M. Jain and S. P. Gupta: Mater. Character., 2003, 51, 243-257.

67. T. M. Chandrashekharaiah and S. A. Kori: Tribol. Int., 2009, 42, 59-65.

68. M. Harun, I. A. Talib and A. R. Daud: Wear, 1996, 194, 54-59.

69. J. Ahn, B. Hwang and S. Lee: J. Therm. Spray Technol., 2005, 14, 251-257.

70. J. K. Mohammeda and E. S. Dwaraka-Dasa: Wear, 1987, 119, 119-130.

71. J. E. Hanafee: Mod. Cast., 1963, 44, 514-520.

72. G. Mrówka-Nowotnik, J. Sieniawski and M. Wierzbińska: J. Achiev. Mater. Manuf. Eng., 2007, 20, 155-158.

73. K. Fushimi, S. Yamamoto, R. Ozaki and H. Habazak: Electrochim. Acta, 2008, 53, 2529-2537.

74. C. Vargel: 'Corrosion of aluminium', 25-43; 2004, Amsterdam, Elsevier.

75. M. V. Kral, P. N. H. Nakashima and D. R. G. Mitchell: Metall. Mater. Trans. A, 2006, 37A, 1987-1997.

76. L. A. Dobrzanski, A. Wlodarczyk-Fligier and M. Adamiak: Int. J. Microstruct. Mater. Prop., 2007, 2, 150-163.

77. J. Vereecken: 'Corrosion control of aluminium - forms of corrosion and prevention', TALAT Lecture, No. 5103, 7-13, 1994.

78. H. Terryn: 'Reactivity of the aluminium surface in aqueous solutions', TALAT Lecture, No. 5102, 2-4, 2006.

79. P. Campestrini, E. P. M. van Westing, H. W. van Rooijen and J. H. W. de Wit: Corros. Sci., 2000, 42, 1853-1861.

80. T. Dimogerontakis, L. Kompotiatis and I. Kaplanoglou: Corros. Sci., 1998, 40, 1939-1951.

81. V. Guillaumin and G. Mankowski: Corros. Sci., 1998, 41, 421438.

82. J. D. Gorman, S. T. Jonhson, P. N. Jonhtson, P. J. K. Paterson and A. G. Hughes: Corros. Sci., 1996, 38, 1977-1990.

83. P. Schmutz and G. S. Frankel: J. Electrochem. Soc., 1998, 145, 2295-2306.

84. F. Eckermann, T. Suter, P. J. Uggowitzer, A. Afseth and P. Schmutz: Electrochim. Acta, 2008, 54, 844-855.

85. Z. Szklarska-Smialowska: Corros. Sci., 1999, 41, 1743-1767.

86. J. C. Seegmiller, R. C. Bazito and D. A. Buttry: 'Corrosion and protection of light metal alloys': Proc. Int. Symp., Vol. 2003, 2935; 2004, Pennington, NJ, Electrochemical Society.

87. O. L. Rocha, C. A. Siqueira and A. Garcia: Metall. Mater. Trans. $A, 2003,34$ A, 995-1006.
88. R. G. Buchheit, R. P. Grant, P. F. Hlava, B. Mckenzie and G. L. Zender: J. Electrochem. Soc., 1997, 144, 2621-2628.

89. D. Landolt: 'Corrosion and surface chemistry of metals'; 2007, Boca Raton, FL, CRC Press.

90. C. Blanc, A. Freulon, M.-C. Lafont, Y. Kihn and G. Manowski: Corros. Sci., 2006, 48, 3838-3851.

91. C. H. Cáceres, M. B. Djurdjevic, T. J. Stockwell and J. H. Sokolowski: Scr. Mater., 1999, 40, 631-637.

92. A. M. Samuel, A. Gotmare and F. H. Samuel: Compos. Sci. Technol., 1995, 53, 301-315.

93. I. Maxwell and A. Hellawell: Acta Metall., 1975, 23, 229-237.

94. H. Men and Z. Fan: Acta Mater., 2011, 59, 2704-2712

95. K. W. Wilcox, A. G. L. Holloway and A. G. Gerber: J. Fluids Eng., 2011, 133, 121304.

96. Z. Guo, N. Saunders, P. Miodownik and J.-P. Schillé: 'Prediction of room temperature mechanical properties in aluminium castings', Proc. Conf. ICAA 11, Aachen, Germany, September 2008, Deutsche Gesellschaft fur Materialkunde e.V, Paper D-480.

97. V. Abouei, H. Saghafian, S. G. Shabestari and M. Zarghami: Mater. Des., 2010, 31, 3518-3524.

98. A. Cibula: J. Inst. Met., 1949-1950, 76, 321-360.

99. A. L. Greer, A. M. Bunn, A. Tronche, P. V. Evans and D. J. Bristow: Acta Mater., 2000, 48, 2823-2835.

100. W. Schneider, M. A. Kearns, M. J. McGarry and A. J. Whitehead: Proc. TMS Annual Meet., (ed. B. J. Welch), 953961; 1998, Warrendale, PA, TMS.

101. T. E. Quested and A. L Greer: Acta Mater., 2004, 52, 3859-3868.

102. B. C. Pai, G. Ramani, R. M. Pillai and K. G. Satyanarayana: J. Mater. Sci., 1995, 30, 1903-1911.

103. Y. Wang, M. Xia, Z. Fan, X. Zhou and G. Thompson: Intermetallics, 2010, 18, 1683-1989.

104. Z. Fan, Y. Wang, M. Xia and S. Arumuganathar: Acta Mater., 2009, 57, 4891-4901.

105. D. H. StJohn, M. Qian, M. A. Easton, P. Cao and Z. Hildebrand: Metall. Mater. Trans. A, 2005, 36A, 1669-1679.

106. T. S. Srivatsan: J. Mater. Sci., 1996, 31, 1375-138.

107. N. Ishizawa, T. Miyata, I. Minato, F. Marumo and S. Iwai: Acta Cryst. B, 1980, 36B, 228-230.

108. Y. Watanabe and Y. Fukui: 'Current issues on multidisciplinary microscopy research and education', 189-198; 2004, Badajoz, Formatex.

109. J. R. Davis: 'ASM speciality handbook: heat-resistant Materials', 9; 1997, Materials Park, OH, ASM International.

110. L. E. Samuels: 'Metals engineering: a technical guide', 245-247; 1988, Materials Park, OH, ASM International.

111. J. A. Lee: in 'Aluminum', (ed. S. K. Das), 145-151; 2003, Warrendale, PA, TMS

112. J. A. Lee and P. S. Chen: 'High strength and wear resistant aluminum alloy for high temperature applications'; 2005, Huntsville, AL, NASA Marshall Space Flight Center.

113. S. Liu, R. Hu, D. Zhao and C. Wang: J. Mater. Sci. Technol., 1995, 11, 369-372.

114. D. Lutz: Ind. Phys., 1996, 2, 26-31.

115. K. Schechtman, I. Blech, D. Gratias and J. W. Cahn: Phys. Rev. Lett., 1984, 53, 1951-1953.

116. T. Fujiwara and T. Yokokawa: Phys. Rev. Lett., 1991, 66, 333336.

117. G. Dell'Acqua, M. Krajčí and J. Hafner: J. Phys. Condens. Matter, 1997, 9, 10725-10738.

118. A. Yamamoto and K. Hiraga: Phys. Rev. B, 1988, 37B, 6207 6214

119. A. Eckert, L. Schultz and B. Urban: Europhys. Lett., 1990, 13, 349-354.

120. U. Mizutani: Mater. Sci. Eng. A, 2000, A294-A296, 464469

121. F. F. Wang, C. G. Zhou, S. K. Gong and H. B. Xu: Mater. Sci. Forum, 2007, 546-549, 2313-2316.

122. U. Köster and B. Schuhmacher: Mater. Sci. Forum, 1987, 22-24, $505-516$

123. A. Singh, M. Watanabe, A. Kato and A. P. Tsai: Mater. Sci. Eng. $A$, 2004, A385, 382-396.

124. W. C. Oliver and W. D. Nix: Acta Metall., 1982, 30, 1335-1347.

125. M. Wollgarten, M. Beyss, K. Urban, H. Liebertz and U. Köster: Phys. Rev. Lett., 1993, 71, 549-552.

126. Z. Chen, Z. He and W. Jie: J. Mater. Sci. Technol., 2007, 23, 619-622.

127. K. T. Kashyap and T. Chandrashekar: Bull. Mater. Sci., 2001, 24, 345-353.

128. Z. Zhu and M. J. Starink: Mater. Sci. Eng. A, 2008, A488, 125133. 